\title{
25 anos dos Cadernos Nietzsche
}

\author{
Scarlett Marton* \\ Ivo da Silva Júnior** \\ Márcio José Silveira Lima*** \\ (Editores)
}

Os Cadernos Nietzsche comemoram neste ano 25 anos de existência, com 55 números publicados. É o momento de os editores que cuidaram da revista desde a sua fundação tomem a palavra.

Em 1996, fundei o GEN - Grupo de Estudos Nietzsche. Inicialmente ligado ao Departamento de Filosofia da USP, expandiuse através do país. Hoje, é um grupo internacional de pesquisa, que reúne estudiosos brasileiros, assim como franceses e italianos. Perseguindo o objetivo de contribuir para fazer avançar a pesquisa Nietzsche, o GEN atua em três frentes: os Cadernos Nietzsche, os Encontros Nietzsche e a coleção Sendas \& Veredas.

\footnotetext{
* Universidade de São Paulo, São Paulo, São Paulo, Brasil.

ORCID https://orcid.org/0000-0002-6869-3371

Correio eletrônico: smarton@usp.br

** Universidade Federal de São Paulo, São Paulo, São Paulo, Brasil.

ORCID https://orcid.org/0000-0003-4171-8759

Correio eletrônico: isjunior@unifesp.br

*** Universidade Federal do Sul da Bahia, Porto Seguro, Bahia, Brasil.

ORCID https://orcid.org/0000-0001-6813-8864

Correio eletrônico: marsil@ufsb.edu.br
} 
Marton, S., Silva Júnior, I. e Lima, M. J. S.

Com os Cadernos Nietzsche, pretendi criar um fórum de debates em torno das múltiplas questões colocadas acerca e a partir da reflexão nietzschiana. Procurando imprimir seriedade aos estudos sobre a filosofia de Nietzsche no país, introduzi vocabulário rigoroso, escolhi traduções que me pareciam as mais apropriadas, adotei a edição das obras completas e da correspondência organizada por Colli e Montinari, segui as normas de citação dos Nietzsche-Studien (Cf. Nietzsche, 1975, 1986, 1988). Desde a sua fundação, em 1996, a revista norteia-se por duas diretrizes básicas: a de trazer ao público brasileiro as mais diferentes leituras do pensamento de Nietzsche, constituindo um espaço de conflito de interpretações, e a de acolher trabalhos de pesquisadores internacionais de renome, estudiosos brasileiros confirmados e pós-graduandos, promovendo um diálogo entre diferentes gerações.

O trabalho, que, na qualidade de editora da revista, realizei com a publicação dos 25 primeiros números, foi engrandecido e aprimorado pelos editores que me sucederam.

Scarlett Marton

$* * *$

Sempre visando à divulgação dos trabalhos publicados nos Cadernos Nietzsche, realizada até então sobretudo por ocasião dos Encontros Nietzsche, tornou-se imperativo construir a sua versão eletrônica. Esta foi uma das primeiras iniciativas que tomei quando assumi a revista a partir do número 26. Uma incursão inicial do GEN no universo eletrônico havia sido realizada por Wilson Frezzatti Jr., mas a revista ela mesma tinha existência apenas na versão impressa. Em 2010, pude levar a bom termo a criação imaterial da revista, com um ISSN próprio, num site dotado de mecanismos de busca

10 | Cad. Nietzsche, Guarulhos/Porto Seguro, v.42, n.3, p. 9-13, setembro/dezembro, 2021. 
e tudo o mais que caracteriza uma edição eletrônica. Um passo seguinte, visando a adequar os Cadernos Nietzsche aos requisitos básicos exigidos para um periódico dito científico, foi inclui-la na base de dados Scielo, que ocorreu em 2012. A manutenção da versão impressa manteve-se e a inclusão no Portal dos Periódicos, da UNIFESP, também, posteriormente, se realizou. Neste ínterim, no entanto, por razões de financiamento, a versão impressa passou, com o tempo, a aparecer após a eletrônica, de modo que, de forma involuntária, esta se impôs àquela como sendo a versão principal da revista.

Ao lado desse trabalho de natureza mais executiva, que, ao longo do tempo contou com inestimáveis contribuições de colegas do GEN, secretariando, obtendo recursos financeiros, revisando o material para publicação, etc., a montagem dos números da revista, temáticos ou não, sempre teve a participação de Scarlett Marton, que se mantém à frente no recebimento de artigos relevantes de autores estrangeiros, e dos demais colegas, que, internamente, repertoriam o que há de relevância para ser publicado, com um duplo objetivo, qual seja, o de trazer novas perspectivas interpretativas do filósofo e o de contribuir para o adensamento da pesquisa nietzschiana em nível nacional.

Com o aumento das exigências das agências de fomento para classificar as revistas, como incremento de informações que a base Scielo nos demanda para aprimorar os periódicos nela inclusos, com os desafios para a obtenção de recursos para a confecção da revista, com as dificuldades de manutenção do site, etc., passei a dividir mais diretamente os trabalhos com Márcio José Silveira Lima, que, desde 2015, tem assumido praticamente a totalidade dos trabalhos executivos.

Ivo da Silva Júnior 
Marton, S., Silva Júnior, I. e Lima, M. J. S.

$* * *$

Recebi como o maior dos desafios de minha vida acadêmica o convite de Ivo da Silva Júnior para assumir a responsabilidade editorial dos Cadernos Nietzsche. Minha resposta positiva veio com um pedido, quase uma condição: a de que ele continuasse à frente da revista, agora compartilhando comigo o trabalho. Naquele ano de 2015, eu mudara de Instituição havia pouco, tendo me transferido para a Universidade Federal do Sul da Bahia, àquela altura umas das quatro mais recentes universidades do Brasil, cujas atividade haviam começado em 2014. Era, portanto, um duplo desafio: contribuir para a construção de algo novo e cuidar para manter o padrão de uma revista já consolidada. Sobre esse último aspecto, a classificação no estrato Al da Qualis-Capes, na área de filosofia, e o pertencimento à base de dados Scielo bem o confirmavam.

Além disso, as mudanças por que passaram os Cadernos Nietzsche desde a sua criação, em 1996, mostravam também o vigor e a força do GEN, que soube dar continuidade a esse belo projeto editorial, apesar das dificuldades que iam se impondo. Sem dúvida, quando assumi parte do trabalho editorial da revista, o fato de, naquele momento, estar ligada a uma Universidade recém-criada, com tudo ainda por construir, não significou um percalço a mais, pois se tratava apenas de dar prosseguimento ao trabalho que o GEN já vinha desempenhando. Por outro lado, a chegada dos Cadernos Nietzsche à UFSB tinha um valor simbólico muito grande, pois era o testemunho de um momento realmente singular para as universidades e para a produção do conhecimento em nosso país. Um momento que, infelizmente, dava seus suspiros finais.

E em meio aos muitos retrocessos que começaram a nos impor, a captação de recursos passou a ser um "drama" particular para manter a periodicidade. Esta tem sido a maior das dificuldades que temos enfrentado. Contudo, se é verdade que essa situação explica por que a versão eletrônica passou a ter primazia sobre a impressa,

12 | Cad. Nietzsche, Guarulhos/Porto Seguro, v.42, n.3, p. 9-13, setembro/dezembro, 2021. 
as próprias condições da divulgação científica também contribuíram para essa nova realidade. Os periódicos têm hoje no mundo virtual seu lócus privilegiado. Também fomos nos tornando o que somos pelo pertencimento às novas condições, sobretudo por integrar uma base de dados importante. Todas as etapas necessárias para que a revista seja publicada passam por constantes modificações, desde a recepção dos artigos até sua publicação, com as tarefas de emissão de pareceres, tradução, revisão, até a diagramação e as novas linguagens e regras de codificação. Nesse percurso, passamos de duas para três edições anuais.

Para o futuro, por certos novos desafios estão postos, e já estamos empenhados em vencê-los.

Márcio José Silveira Lima

\section{Referências}

NIETZSCHE, Friedrich. Briefwechsel: Kritische Gesamtausgabe (KGB). (Organizada por Giorgio Colli e Mazzino Montinari ). Berlim: Walter de Gruyter \& Co., 1975.

. Sämtliche Briefe: Kritische Studienausgabe (KSB), 8 Vols. (Organizada por Giorgio Colli e Mazzino Montinari ). Berlim: Walter de Gruyter \& Co., 1986.

. Sämtliche Werke. Kritische Studienausgabe (KSA), 15 vols. (Organizada por Giorgio Colli e Mazzino Montinari), Berlim: Walter de Gruyter \& Co., 1988. 